\title{
Nutritional evaluation of the peels from Citrullus lanatus and Manihot esculenta, an insight into the conversion of waste to food
}

\author{
${ }^{1 *}$ Tsado A. Ndarubu, ${ }^{2}$ Gana David, ${ }^{1}$ Ibrahim A. Habiba, ${ }^{3}$ Jiya A. Gboke, ${ }^{1}$ Zubairu Rakiya, ${ }^{4}$ Okoli N. \\ Rosemary, ${ }^{5}$ Danazumi Nathaniel
}

*Correspondence:

Tsado A. Ndarubu

infoamosndarubu@gmail.com

Mobile-+2348032920909

${ }^{1}$ Department of Biological sciences, Niger State polytechnic, P. M. B 01, Zungeru, Niger State, Nigeria.

${ }^{2}$ Department of Geography and Environmental Management, University of Abuja, Nigeria.

${ }^{3}$ Department of Biological Sciences, Federal Polytechnic, Bida, Niger State, Nigeria. ${ }^{4}$ Department of Science Laboratory Technology, Federal Polytechnic, Oko, Anambra State, Nigeria.

${ }^{5}$ Department of Chemical Science, Federal Polytechnic, Bida, Niger State, Nigeria

Received: 22 April 2021, Revised: 25 May 2021

Published: 01 June 2021

\section{ABSTRACT}

Background: Huge quantity of cassava and watermelon wastes are daily discharged to the environment with unwholesome consequences. Therefore, research into the effective utilization of these agricultural by-products is of global interest.

Methods: The present study evaluated the proximate, minerals, and amino acid compositions of cassava and watermelon peels using standard procedures.

Results: The results revealed that carbohydrate is the most abundant proximate contents of both the cassava $(82.14 \pm 0.42 \%)$ and watermelon $(62.58 \pm 0.78 \%)$ peel, followed by crude fiber $(5.51 \pm 0.06 \%$ and $18.90 \pm 0.04 \%)$, moisture $(8.31 \pm 0.04 \%$ and $5.20 \pm 0.07 \%)$, crude ash $(1.25 \pm 0.03 \%$ and $7.25 \pm 0.04 \%)$ for cassava and watermelon peels respectively, while crude fat $(0.98 \pm 0.03 \%$ and $3.92 \pm 0.06 \%)$ is the least abundant proximate in both samples. Magnesium is the most abundant mineral contents of both the cassava $(79.50 \pm 4.45 \mathrm{Mg} / 100 \mathrm{~g})$ and watermelon $(75.53 \pm 3.70 \mathrm{Mg} / 100 \mathrm{~g})$ peel, followed by sodium $(62.35 \pm 0.79 \mathrm{Mg} / 100 \mathrm{~g}$ and $52.24 \pm 3.24 \mathrm{Mg} / 100 \mathrm{~g})$, potassium $(22.12 \pm 1.34$ and $32.65 \pm 2.01 \mathrm{mg} / 100 \mathrm{~g})$ for cassava and watermelon peels respectively while copper $(0.73 \pm 0.05 \mathrm{Mg} / 100 \mathrm{~g}$ and $0.67 \pm 0.64 \mathrm{Mg} / 100 \mathrm{~g})$ was the least abundant minerals in both samples. The total amino acid compositions of $66.31 \pm 4.56 \mathrm{~g} / 100 \mathrm{~g}$ and $41.80 \pm 2.68 \mathrm{~g} / 100 \mathrm{~g}$ were recorded for cassava and watermelon peel. Glutamic acid $(9.96 \pm 0.06 \mathrm{~g} / 100 \mathrm{~g})$ and leucine $(4.03 \pm 0.05 \mathrm{mg} / 100 \mathrm{~g})$ the most abundant amino acid in cassava and watermelon seed respectively.

Conclusion: In conclusion, the peels of cassava and water melon examined, have appreciable levels of nutrients compositions that can be incorporated into human and animal feed formulation.

Keywords: Proximate; minerals; amino acid; cassava peels; water-melon peels

Citation: Tsado, A.N., Gana, D., Ibrahim, A.H., Jiya, A.G., Zubairu, R., Okoli N.R., and Danazumi N. (2021). Nutritional evaluation of the peels from Citrullus lanatus and Manihot esculenta, an insight into the conversion of waste to food. AROC in Food and Nutrition, 01(01);01-07

\subsection{Introduction}

One of the most common problems in food processing is the disposal of the waste material generated. This "waste material" produces ecological problems related to the proliferation of insects and rodents and an economical burden because of transportation to repositories, therefore strategies for the profitable use of these materials are needed (Hussein et al., 2011). In the food processing industry, edible portions of fruits are processed into products such as puree, canned slices, juice, and pickles, whereas peels often will be discarded as waste since it is not currently utilized for commercial purposes (Ajila et al., 2007). Peels are also a promising source of useful compounds because of their favorable technological or nutritional properties (Schieber et al., 2001).
Watermelon [(Citrullus lanatus (Thunb.)], belonging to the Cucurbitaceae family is widespread in tropical and subtropical regions of the world (Achu et al., 2005). Watermelon is primarily consumed as a fruit because of its sweet flavor and high nutritional value. It has been widely used in several regions of the world, especially in Africa and 
Asia, not only as a source of nutrition but also as a folk remedy for the treatment of diseases (Artwatermelon, 2007; Ziyada and Elhussien, 2008). Watermelon peel is recently gaining importance due to its nutritional and medicinal value. It has high nutritional value and is utilized for human consumption as snacks after salting and roasting in Arabian and Asian regions (Ziyada and Elhussien, 2008).

Cassava (Manihot esculenta Cranz) is a dicotyledonous plant, belonging to the family Euphorbiaceae (Alves, 2002). It is a perennial shrub, 2 to $4 \mathrm{~m}$ in height, and is mainly propagated from stem cuttings. Cassava forms a staple food for an estimated $\mathbf{5 0 0}$ million people in the tropics. It is widely grown in most countries in the tropical regions of Africa, Latin America, and Asia. The crop is an important source of carbohydrate for humans and animals, having higher energy than other root crops, $610 \mathrm{~kJ} / 100 \mathrm{~g}$ fresh weight. Dried cassava root has energy similar to the cereals (FAO, 1990). In Africa, the continent with the largest cassava production, about $93 \%$ of the produce is used as food (Nweke et al., 2002). Cassava can be transformed into various products such as 'gari', 'fufu', 'lafun' and many other West African traditional dishes (Afoakwa et al., 2010).

Cassava processing factories are tremendous and the impacts on the environment could be annihilated thus giving rise to the need for proper management and release of these wastes. More of the waste product from cassava processing come from mainly Garri and starch processing factories and will only be useful if the peels can be incorporated into the livestock diet formulation. The use of cassava peels in livestock feeding would help to solve the trouble of its disposal as a waste product and likewise to bring down the monetary value of livestock production (Somendrika et al., 2017). It is, therefore, necessary to investigate the nutritional composition of watermelon and cassava peel in order to elucidate their chemical and nutritional composition, optimize their utilization and ascertain their usefulness to the economy, health, and nutritional benefits.

\section{Material and methods}

\subsection{Sample Collection and preparation}

The cassava and watermelon peels (Figure 1) were obtained from Bosso market in Minna, Niger state,
Nigeria in March 2018. The peels were washed, allowed to drain and placed on a foil paper. The seeds were air dried for 2 weeks. The dried samples were pulverized using electronic blending machine and stored in plastic container prior to the analysis

\subsection{Reagents and Chemicals}

All chemicals used were of analytical grade and were products of Sigma Chemical Co., USA. They include Mayer's Reagent, Wagner's Reagent phosphate

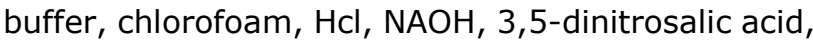
$\mathrm{FeCL}_{3}$, Conc ammonium hydroxide, hexane, Conc $\mathrm{H}_{2} \mathrm{SO}_{4}$.

\subsection{Proximate Analysis}

The proximate (crude proteins, crude fiber, moisture content, ash content, crude fat and carbohydrate) analysis of the sample was carried out by the methods of AOAC, (1990) as reported by Onwuka, (2005). The moisture content of was determine by oven drying two grams ( $2 \mathrm{~g}$ ) of the sample in an oven (Gallenkamp, UK) at $105^{\circ} \mathrm{C}$ for 24 hrs. The dried sample was then cooled in a desiccator for 30 minutes and weighed.

The ash content was determined by the incineration of five grams $(5 \mathrm{~g})$ of the sample in a muffle furnace at $550^{\circ} \mathrm{C}$ for $2 \mathrm{hrs}$. Crude lipid (CL) was Soxhlet extracted from three grams $(3 \mathrm{~g})$ of the sample with petroleum ether for $10 \mathrm{hrs}$. Crude fibre (CF) content was determined by treating $1 \mathrm{~g}$ of deffated sample with $1.25 \%$ (w/v) $\mathrm{H}_{2} \mathrm{SO}_{4}$ and $1.25 \%$ (w/v) $\mathrm{NaOH}$. The nitrogen $(\mathrm{N})$ content was estimated by microKjeldahl method and crude protein (CP) content calculated as $\mathrm{N} \% \times 6.25$. The available carbohydrate ( $\mathrm{CHO}$ ) was calculated using the formula: \% carbohydrate $=100-\left(M+P+F+A+F_{2}+L\right)$.

Where

$\mathrm{M}=\%$ Moisture, $\mathrm{P}=\%$ Protein, $\mathrm{F}_{1}=\%$ Fat, $\mathrm{A}=\%$

Ash $\quad \mathrm{F}_{2}=\%$ Crude Fiber $\quad \mathrm{L}=\%$ Crude Lipid

\subsection{Determination of Amino Acid Profile}

The Amino acid compositions of the samples were determined using methods described by Benitez (1989). The known sample was dried to constant weight, defatted, hydrolyzed, evaporated in a rotary evaporator and loaded into the Applied Biosystems PTH Amino Acid Analyzer. The sample was defatted using chloroform/methanol mixture of ratio $2: 1$. About $500 \mathrm{mg}$ of the sample was put in extraction 
thimble and extracted for 15 hours in soxhlet extraction apparatus (AOAC, 1990).

The defatted sample was weighed into glass ampoule. $7 \mathrm{ml}$ of $6 \mathrm{NHCL}$ was added and oxygen was expelled by passing nitrogen into the ampoule (this is to avoid possible oxidation of some amino acids during hydrolysis e.g methionine and cystine). The glass ampoule was then sealed with Bunsen burner flame and put in an oven preset at $105^{\circ} \mathrm{C} \pm 5^{\circ} \mathrm{C}$ for 22 hours. The ampoule was allowed to cool before broken open at the tip and the content was filtered to remove the humins. It should be noted that tryptophan is destroyed by $6 \mathrm{~N} \mathrm{HCL}$ during hydrolysis. The filtrate was then evaporated to dryness using rotary evaporator (AOAC, 2006).

The residue was dissolved with $5 \mathrm{ml}$ to acetate buffer $(\mathrm{pH} 2.0)$ and stored in plastic specimen bottles, which were kept in the freezer. A 60 microlitre of the sample was dispensed into the cartridge of the analyzer. The analyzer is designed to separate and analyze free acidic, neutral and basic amino acids of the hydrolysate. An integrator attached to the Analyzer calculates the peak area proportional to the concentration of each of the amino acids (Benitez, 1989).

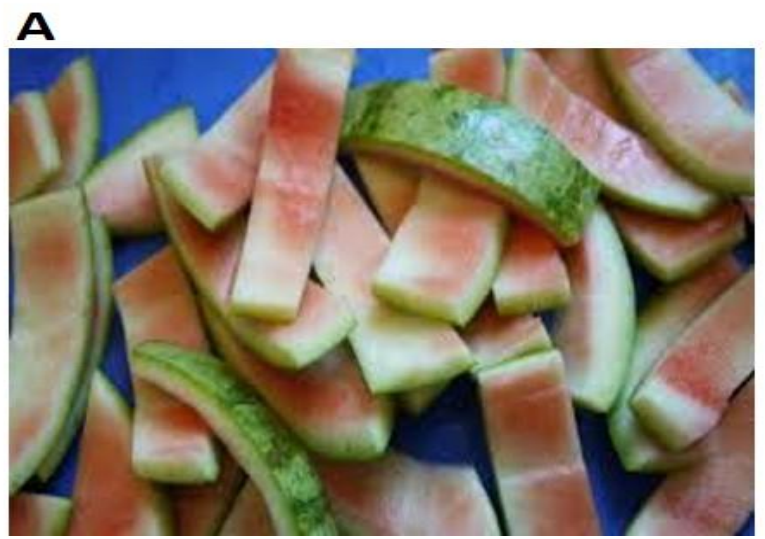

\subsection{Mineral analysis}

The concentration of sodium, potassium, calcium, magnesium, copper, manganese, iron, zinc and phosphorus in the cassava peel and water melon seed were analysed according to AOAC (1990). Ten grams $(10 \mathrm{~g})$ of each of the samples was heated over flame and ashed in muffle furnace at $450^{\circ} \mathrm{C}$ for 8 hours. Ten $(10 \mathrm{~mL})$ of diluted $\mathrm{HCL}$ was added to the ash and boiled for 5 minutes. The boiled ash was made up to $100 \mathrm{ml}$ with distilled water. Analysis was performed in triplicate using atomic absorption spectrophotometer according to the standard methods of AOAC (2000).

\subsection{Statistical analysis}

Data collected were subjected to statistical analysis using the statistical package for social science version 21.0 and express as mean \pm standard error of mean (SEM). Statistical significance of the results between groups was determined using One-way analysis of variance (ANOVA) followed by Duncans multiple range test (DMRT) Differences in mean were considered to be significant at $p<0.05$ (Adamu and Johnson, 1997).

\section{B}

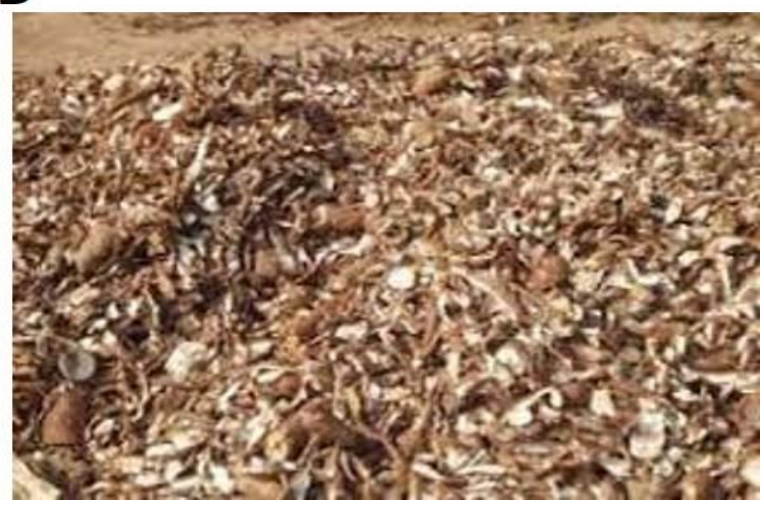

Figure 1: Waste product use in this study $(A)$ water melon peel $(B)$ cassava peel collected from Bosso market in Minna, Niger state, Nigeria

\subsection{Results}

\subsection{Proximate Compositions}

The proximate compositions of cassava peel and water melon seed are shown in Table 1: The results revealed that carbohydrate is the most abundant proximate contents of both the cassava $(82.14 \pm 0.42 \%)$ and water melon $(62.58 \pm 0.78 \%)$ peel, followed by crude fibre $(5.51 \pm 0.06 \%$ and
$18.90 \pm 0.04 \%)$, moisture $(8.31 \pm 0.04 \%$ and $5.20 \pm 0.07 \%)$ crude ash $(1.25 \pm 0.03 \%$ and $7.25 \pm 0.04 \%)$ for both cassava and water melon peels respectively while crude fat $(0.98 \pm 0.03 \%$ and $3.92 \pm 0.06 \%$ ) was the least abundant proximate in the both samples. Water melon peel contains higher ash, proteins, fat and crude fiber contents than the cassava peel while cassava peel contains higher proteins, fat and carbohydrate contents 
Table 1: Proximate compositions of cassava peel and water melon peel

\begin{tabular}{lll}
\hline & $\begin{array}{l}\text { Cassava } \\
\text { Peel (\%) }\end{array}$ & $\begin{array}{l}\text { Water melon } \\
\text { Peel (\%) }\end{array}$ \\
\hline Moisture & $8.31 \pm 0.04^{\mathrm{b}}$ & $5.20 \pm 0.07^{\mathrm{b}}$ \\
Ash & $1.25 \pm 0.03^{\mathrm{ab}}$ & $7.25 \pm 0.04^{\mathrm{c}}$ \\
Protein & $1.81 \pm 0.08^{\mathrm{b}}$ & $2.15 \pm 0.07^{\mathrm{a}}$ \\
Crude fibre & $5.51 \pm 0.06^{\mathrm{c}}$ & $18.90 \pm 0.04^{\mathrm{d}}$ \\
Fat & $0.98 \pm 0.03^{\mathrm{a}}$ & $3.92 \pm 0.06^{\mathrm{ab}}$ \\
Carbohydrate & $82.14 \pm 0.42^{\mathrm{d}}$ & $62.58 \pm 0.78^{\mathrm{e}}$
\end{tabular}

Data are Mean \pm SEM of triplicate determination. Value with different superscript alphabet are significantly different $(p<0.05)$

\subsection{Minerals Compositions}

The minerals compositions of cassava and water melon peel are shown in Table 2: Results revealed that magnesium is the most abundant minerals contents of both the cassava $(79.50 \pm 4.45 \mathrm{Mg} / 100 \mathrm{~g})$ and water melon $(75.53 \pm 3.70 \mathrm{Mg} / 100 \mathrm{~g})$ peel, followed by sodium $(62.35 \pm 0.79 \mathrm{Mg} / 100 \mathrm{~g}$ and $52.24 \pm 3.24 \mathrm{Mg} / 100 \mathrm{~g})$, potassium (22.12 \pm 1.34 and $32.65 \pm 2.01 \mathrm{mg} / 100 \mathrm{~g}$ ) for both cassava and water melon peels respectively while copper $(0.73 \pm 0.05$ $\mathrm{Mg} / 100 \mathrm{~g}$ and $0.67 \pm 0.64 \mathrm{Mg} / 100 \mathrm{~g}$ ) is the least abundant mineral in the both samples. Water melon peels contain higher copper, manganese, zinc, calcium and potassium while other minerals were higher in cassava peel

Table 2: Mineral compositions of water melon and cassava peels

\begin{tabular}{lcc}
\hline Minerals & $\begin{array}{l}\text { Cassava Peel } \\
(\mathrm{Mg} / 100 \mathrm{~g})\end{array}$ & $\begin{array}{c}\text { Water melon } \\
\text { Peel }(\mathrm{Mg} / 100 \mathrm{~g})\end{array}$ \\
\hline Copper & $0.73 \pm 0.05^{\mathrm{a}}$ & $0.67 \pm 0.64^{\mathrm{a}}$ \\
Iron & $29.09 \pm 1.04^{\mathrm{d}}$ & $14.19 \pm 0.29^{\mathrm{c}}$ \\
Manganese & $1.69 \pm 0.02^{\mathrm{b}}$ & $3.72 \pm 0.95^{\mathrm{b}}$ \\
Zinc & $12.90 \pm 0.90^{\mathrm{c}}$ & $23.10 \pm 0.37^{\mathrm{d}}$ \\
Calcium & $24.13 \pm 0.46^{\mathrm{d}}$ & $30.45 \pm 0.75^{\mathrm{e}}$ \\
Magnesium & $79.50 \pm 4.45^{\mathrm{f}}$ & $75.53 \pm 3.70^{\mathrm{g}}$ \\
Sodium & $62.35 \pm 0.79^{\mathrm{e}}$ & $52.24 \pm 3.24^{\mathrm{f}}$ \\
Potassium & $22.12 \pm 1.34^{\mathrm{d}}$ & $32.65 \pm 2.01^{\mathrm{e}}$ \\
phosphorus & $20.18 \pm 0.57^{\mathrm{d}}$ & $18.75 \pm 0.65^{\mathrm{c}}$ \\
\hline
\end{tabular}

Data are Mean \pm SEM of triplicate determination. Value with different superscript alphabet are significantly different $(p<0.05)$

\subsection{Amino acid compositions}

The amino acid compositions of cassava and water melon peels are shown in Table 3: Results revealed that the total amino acid of $66.31 \pm 4.56 \mathrm{~g} / 100 \mathrm{~g}$ and $41.80 \pm 2.68 \mathrm{~g} / 100 \mathrm{~g}$ was recorded for cassava and water melon peels respectively. Glutamic acid $9.96 \pm 0.06 \mathrm{~g} / 100 \mathrm{~g}$ was the most abundant amino acid in cassava peel followed by aspartic acid $(6.70 \pm 0.03 \mathrm{~g} / 100 \mathrm{~g})$ and alanine $(5.84 \pm 0.07$ $\mathrm{g} / 100 \mathrm{~g})$, however, in water melon peel, leucine $(4.03 \pm 0.05 \mathrm{mg} / 100 \mathrm{~g})$ was the most abundant amino acid followed by arginine $(3.27 \pm 0.03 \mathrm{~g} / 100 \mathrm{~g})$ and glutamic acid $(3.48 \pm 0.02 \mathrm{~g} / 100 \mathrm{~g})$.

Table 3: Amino acid composition of water melon and cassava peels

\begin{tabular}{lll}
\hline Amino Acid & $\begin{array}{l}\text { Cassava } \\
(\mathbf{g} / \mathbf{1 0 0 g})\end{array}$ & $\begin{array}{l}\text { Watermelon } \\
(\mathbf{g} / \mathbf{1 0 0 g})\end{array}$ \\
\hline Leucine & $4.79 \pm 0.03^{\mathrm{cd}}$ & $4.03 \pm 0.05^{\mathrm{d}}$ \\
Lysine & $4.77 \pm 0.02^{\mathrm{cd}}$ & $2.39 \pm 0.05^{\mathrm{bc}}$ \\
Isoleucine & $3.08 \pm 0.04^{\mathrm{c}}$ & $3.21 \pm 0.02^{\mathrm{c}}$ \\
Phenylalanine & $1.42 \pm 0.03^{\mathrm{b}}$ & $2.66 \pm 0.01^{\mathrm{bc}}$ \\
Trytophan & $0.73 \pm 0.04^{\mathrm{a}}$ & $0.74 \pm 0.03^{\mathrm{a}}$ \\
Valine & $3.62 \pm 0.05^{\mathrm{c}}$ & $3.21 \pm 0.05^{\mathrm{c}}$ \\
Methionine & $1.35 \pm 0.06^{\mathrm{b}}$ & $0.59 \pm 0.01^{\mathrm{a}}$ \\
Proline & $1.12 \pm 0.03^{\mathrm{b}}$ & $1.73 \pm 0.02^{\mathrm{b}}$ \\
Arginine & $8.43 \pm 0.05^{\mathrm{f}}$ & $3.27 \pm 0.03^{\mathrm{c}}$ \\
Tyrosine & $2.58 \pm 0.06^{\mathrm{bc}}$ & $2.06 \pm 0.03^{\mathrm{bc}}$ \\
Histidine & $2.11 \pm 0.05^{\mathrm{bc}}$ & $1.09 \pm 0.05^{\mathrm{b}}$ \\
Cystine & $0.73 \pm 0.04^{\mathrm{a}}$ & $0.60 \pm 0.03^{\mathrm{a}}$ \\
Alanine & $5.84 \pm 0.07^{\mathrm{d}}$ & $3.41 \pm 0.03^{\mathrm{c}}$ \\
Glutamic acid & $9.96 \pm 0.06^{\mathrm{g}}$ & $3.48 \pm 0.02^{\mathrm{c}}$ \\
Glycine & $5.70 \pm 0.05^{\mathrm{d}}$ & $2.33 \pm 0.06^{\mathrm{bc}}$ \\
Threonine & $1.22 \pm 0.05^{\mathrm{b}}$ & $2.16 \pm 0.02^{\mathrm{bc}}$ \\
Serine & $2.16 \pm 0.03^{\mathrm{bc}}$ & $1.62 \pm 0.01^{\mathrm{b}}$ \\
Aspartic acid & $6.70 \pm 0.03^{\mathrm{e}}$ & $3.22 \pm 0.02^{\mathrm{c}}$ \\
Total & $66.31 \pm 4.56$ & $41.80 \pm 2.68^{\mathrm{a}}$
\end{tabular}

Data are Mean \pm SEM of triplicate determination. Value with different superscript alphabet are significantly different $(p<0.05)$ 


\subsection{Discussion}

The study showed that watermelon seed and cassava peel contain nutritious compounds. The present study showed carbohydrate is the most abundant proximate contents of both the cassava $(82.14 \pm 0.42 \%)$ and watermelon (62.58 $\pm 0.78 \%)$ peels. Results of the present study are in agreement with reported values of $62.0 \%$ and $72.50 \%$ (Somendrika et al., 2017). Lower than values ranging from $87 \%$ to $89 \%$ (Akpabio et al., 2012) and higher than values of $35.83 \%$ reported in other findings (Adegbola et al., 2016). This generally shows that cassava peels are rich in sugar, which is a serious source of vitality in the animal feedstuff.

Moisture is an important parameter in the preservation of cassava flour; very high levels greater than $14 \%$ allow for microbial growth and therefore low levels are favorable and give a relatively long shelf life (Edet et al., 2017). The cassava peel and watermelon peels in this study show good moisture levels and hence delivers the potential for better shelf life. Other findings show that the results obtained from this study are low (Akpabio et al., 2012). The ash content is used as a benchmark to determine the mineral constituent (Olufunke et al., 2010). This result shows that cassava peels and watermelon peel have low-fat content. These results correspond to values reported in other findings (Somendrika et al., 2017). Nevertheless, these values were higher than those reported in another study (Okpako et al., 2008), The fiber contents of cassava peel $(5.51 \pm 0.06 \%)$ obtained are comparatively lower to $21.1 \%$ as observed in the pulp and $8.2 \%$ in the peels, reported in another study (Ravindran et al., 2008). These values were higher than reported values of $(0.60-0.88 \%)$, but comparable with reported values in other surveys (Christopher et al., 2016)

The high protein contents of watermelon and cassava peels could serve as a protein supplementary source in animal and human diets. This protein content is of particular nutritional significance since it has been suggested that amino acid supplementation is important in meeting a substantial proportion of an animal's protein and energy requirements (Doherty et al., 2007). Proteins are also essential for continuous replenishment of the endogenous protein that is lost due to infections with gastro-intestinal helminths (Holmes, 1993).

It is also of remarkable interest that the cassava peel and watermelon peel have a high deposit of mineral elements. The results obtained revealed that magnesium is the most abundant minerals contents of both the cassava $(79.50 \pm 4.45 \mathrm{Mg} / 100 \mathrm{~g})$ and watermelon $(75.53 \pm 3.70 \mathrm{Mg} / 100 \mathrm{~g})$ peel, followed by sodium (62.35 $\pm 0.79 \mathrm{Mg} / 100 \mathrm{~g}$ and $52.24 \pm 3.24 \mathrm{Mg} / 100 \mathrm{~g}$ ), potassium (22.12 \pm 1.34 and $32.65 \pm 2.01 \mathrm{mg} / 100 \mathrm{~g})$ for both cassava and watermelon peels respectively while copper $(0.73 \pm 0.05 \mathrm{Mg} / 100 \mathrm{~g}$ and $0.67 \pm 0.64 \mathrm{Mg} / 100 \mathrm{~g}$ ) is the least minerals in both samples. Calcium is required for the formation and maintenance of bones and teeth thus, preventing osteoporosis. It is also needed for normal blood clotting and nerve function. Interestingly, even Fe, which is commonly deficient in many plant-based diets, was found in abundance in cassava peel and watermelon peel. Iron is a necessary component of hemoglobin and myoglobin for oxygen transport and cellular processes of growth and division (Rouault, 2006).

Iron is also an essential trace element for the normal functioning of the central nervous system and in the oxidation of carbohydrates, proteins, and fats (Fretham et al., 2011). Iron also has a role in energy metabolism as it facilitates the transfer of electrons in the electron transport chain for the formation of ATP (Rouault, 2006). The presence of $\mathrm{Zn}$ in high amounts in watermelon and the cassava peel are of special interest in view of the importance of the inclusion of $\mathrm{Zn}$ in the diet of animals and humans (Fretham et al., 2011). Zinc is essential for the synthesis of DNA, RNA, insulin, and function and/or structure of several enzymes Doherty et al., 2007). Zinc is also required for cell reproduction and growth especially sperm cells. In addition, $\mathrm{Zn}$ is known for its anti-viral, antibacterial, anti-fungal, and anti-cancer properties (Doherty et al., 2007).

The watermelon and cassava peels contained $\mathrm{Cu}$, which is considered to have strong effects on the immune system (Djoko et al., 2015). Copper is involved in stimulating the body's defense system, as it is active in neutrophil production and affects phagocyte killing ability (Wadas et al., 2007). Copper in combination with $\mathrm{Zn}$ plays a role in superoxide dismutase activity and the removal of oxygen free radicals. It is, therefore, a key component in the protective mechanism of cellular membranes against superoxide free radicals damage (Chan et al., 1998). In addition, the copper-containing enzyme, ceruloplasmin has been shown to exhibit anti-inflammatory activity, which may prove beneficial in mastitis cases (Chan et al., 1998). Collectively, the mineral composition of watermelon and cassava peels will play a significant role in nutritional, medicinal, and therapeutic values, and thus worthy of exploration in animal diet 


\subsection{Conclusion}

In conclusion, the peels of cassava and watermelon examined, have appreciable levels of nutrients compositions. The proximate, minerals, and amino acid analysis revealed that these peels are rich in nutrients especially in carbohydrates. It also contains significant amounts of minerals amino acid profile. With these findings, cassava and water melon peels can be incorporated into animal feed formulation.

Author Contribution: All authors contributed to the manuscript. have read and agreed to the published version of the manuscript.

Conflicts of interest: The authors declare no conflicts of interest.

\section{Funding: This research receives no funding}

Data availability statement: Not applicable

Acknowledgments: We would like to acknowledge the support of the technical staff of the Biochemistry Department, Federal University of Technology Minna, Nigeria

\section{References}

A.O.A.C., (1990). Association of Official Analytical Chemists. Official Methods of Analysis of the AOAC, 15th Edn., Washington, D.C.

Achu, B.M., Fokou, E., Tchiegang, C., Fosto, M. and Tchouanguep, F.M. (2005). Nutritive value of some Cucurbitaceae oilseeds from different regions in Cameroon. African Journal of Biotechnology, 4, 1329-1334.

Adegbola, A.A., and Asaolu O. (2006). Preparation of cassava peels for use in small ruminant production in Western Nigeria. In: Proceeding of a Workshop Held at the University of Alexandria, Egypt, Preston T. R. and Nuwanyakpa, M. Y. (eds). 105-115.

Afoakwa E.O (2010). Acidification and Starch Behaviour during Co-Fermentation of Cassava and Soybean into Gari. International Journal of Food Sciences and Nutrition, 61(5) :449- 462.

Ajila, C.M., Naidu, S.G. Bhat, K.A. and Prasada, R. (2007). Bioactive compounds and antioxidant potential of mango peel extract. Food Chemistry, 105: 982-988

Akpabio UD, Akpakpan AE, Udo IE, and Nwokocha GC. (2012). Comparative study on the physicochemical properties of two varieties of cassava peels (Manihot utilissima Pohl). International Journal of Environment and Bioenergy, 2(1):19-32.

Alves, A. A. C. 2002. Cassava botany and physiology. In Hillocks, R. J., Thresh, J. M. and Bellotti, A. C. (Eds), Cassava biology, production and utilization. CABI Publishing, Wallingford, UK, 67-89

Artwatermelon (2007). http://www.foodreference.com. (Accessed on Web12.05.2021).

Benitez, L. V. (1989). Amino acid and fatty acid profiles in aquaculture nutrition studies. Fish nutrition research in asia, 2335.

Chan, S., Gerson, B., \& Subramaniam, S. (1998). The role of copper, molybdenum, selenium, and zinc in nutrition and health. Clinics in laboratory medicine, 18(4), 673-685.

Christopher IN, Onyekwe CE, Justus IO, Nkwoada A. (2016). The proximate analysis and biochemical composition of the waste peels of three cassava cultivars. International Journal of Scientific Engineering and Applied Science (IJSEAS). 2) 11.

Djoko, K. Y., Cheryl-lynn, Y. O., Walker, M. J., \& McEwan, A. G. (2015). The role of copper and zinc toxicity in innate immune defense against bacterial pathogens. Journal of Biological Chemistry, 290(31), 1895418961.

Doherty, C. P. (2007). Host-pathogen interactions: the role of iron. The Journal of nutrition, 137(5), 1341-1344.

Edet, E.E., Onwuka, G.I., and Orieke, C.O.M. (2017). Nutritonal properties of composite flour (Blends of Rice (Oryza sativa), acha (Digitaria exilis) and soybeans (Glycine max) and sensory properties of noodles produced from the flour. Asian Journal of Advances in Agricultural Research.;1(2):113.

FAO, (1990). Roots, tubers, cassavas and cassavas in human nutrition. FAO, Rome, Italy.

Fretham, S. J., Carlson, E. S., \& Georgieff, M. K. (2011). The role of iron in learning and memory. Advances in Nutrition, 2(2), 112121. 
Holmes, P. H. (1993). Interactions between parasites and animal nutrition: the veterinary consequences. Proceedings of the nutrition society, 52(1), 113-120.

Hussein, A.M.S., Kamil, M.M. Mohamed, G.F (2011). Physicochemical and sensorial quality of semolina defatted guava seed flour composite pasta. Journal of American Science 7(6): 623-629.

Nweke, F. I., Spencer, D. S. C. and Lynam, J. K. 2002. The cassava transformation: Africa's best-kept secret. Michigan University Press, USA.

Oboh GO. and Akindahunsi AA (2003). Biochemical changes in cassava products (flour \& gari) subjected to Saccharomyces cerevisae solid media fermentation. Food Chem. 82:599602.

Okpako CE, Ntui Vo, Osuagwu AN, Obasi FI. (2008). Proximate composition and cyanide content of cassava peels fermented with Aspergillus niger and Lactobacillus rhamnosus. Food, Agriculture and Environment (JFAE). 2008;6(2):251-255

Olufunke, O.E., Ogugua, C.A., Hans, P.B., Thaddeus, C.E. (2010). Protein enrichment of cassava pee by submerged fermentation with Trichoderma viride (ATCC 36316). African Journal of Biotechnology, 9(2):187194.

Onwuka, G. I. (2005). Food analysis and instrumentation; theory and practice. Nephthalic Prints, Surulere, Lagos, Nigeria, $219 \mathrm{p}$

Ravindran V, Kornegay Webb Jr, KE, Rajaguru ASB. (2008) Nutrient characterization of some feed stuffs of Sri Lanka. J. Nut. Agric. Soc. 19:19-32.

Rouault, T. A. (2006). The role of iron regulatory proteins in mammalian iron homeostasis and disease. Nature chemical biology, 2(8), 406-414.

Schieber, A., Stintzing, F.C. and Carle, R. (2001). By-products of plant food processing as a source of functional compounds-recent developments. Trends Food Science and Technology, 12(11): 401-413.

Somendrika MAD, Wickramasinghe I, Wansapala MAJ, Peiris S. (2017). Nutritiona I composition of cassava cultivar "CARI555". Pakistan Journal of Nutrition, 16:216220.

Wadas, T. J., Wong, E. H., Weisman, G. R., \& Anderson, C. J. (2007). Copper chelation chemistry and its role in copper radiopharmaceuticals. Current pharmaceutical design, 13(1), 3-16.

Ziyada, A.K., Elhussien, S.A. (2008). Physical and chemical characteristics of Citrullus lanatus Var. Colocynthoide seed oil. Journal of Phyisical Science 19, 69-75. 